\title{
Increased release of glucuronoxylomannan antigen and induced phenotypic changes in Trichosporon asahii by repeated passage in mice
}

\author{
REIKO KARASHIMA, YURIKO YAMAKAMI, EIJI YAMAGATA, ISSEI TOKIMATSU, \\ KAZUFUMI HIRAMATSU and MASARU NASU \\ Second Department of Internal Medicine, Oita Medical University, Hasama-machi, Oita 879-5593, Japan
}

\begin{abstract}
Clinically important fungi such as Candida albicans and Cryptococcus neoformans are known to undergo phenotypic changes after repeated subculture or passages in vivo. However, there are no reports describing this phenomenon in Trichosporon species. This study investigated whether in-vivo passages of environmental isolates of Trichosporon asahii in mice changes their phenotype; three environmental isolates and 14 clinical isolates (from deep-seated infections) were used. The shape of the colony and cell type were observed, and the titre of glucuronoxylomannan (GXM) antigen and concentration of $(1 \rightarrow 3)$ - $\beta$-D-glucan were measured for each isolate. Changes in these features were also examined after three passages of the environmental isolates in mice. The shape of colonies and cell types were clearly different in environmental and clinical isolates. Furthermore, the clinical isolates released significantly higher levels of GXM antigen than environmental isolates (titre: $\log _{2} 9.4 \mathrm{SD} 0.7$ versus $\log _{2} 5.4 \mathrm{SD} 1.4$ ). The phenotype of passaged isolates was significantly different from the original environmental isolates with respect to the morphology of colonies and cell type and GXM release (titre: $\log _{2}$ 10.0 SD 0.7 versus $\log _{2} 5.4 \mathrm{SD} 1.4$ ). These results suggest that the phenotypic changes in T. asahii occur as a result of in-vivo passages. This process may allow a proportion of the fungal population to escape eradication by the host immune system, as GXM antigen is considered to protect the fungi against phagocytosis by polymorphonuclear leucocytes and monocytes in vivo.
\end{abstract}

\section{Introduction}

Trichosporon asahii is one of a number of opportunist mycotic pathogens that can cause life-threatening infections in immunocompromised patients. Deep-seated trichosporonosis is mainly observed in neutropenic patients receiving chemotherapy for haematological malignancies and solid tumours. This systemic disease is associated with morbidly severe conditions, such as progressive respiratory failure, renal failure and disseminated intravascular coagulation syndrome, and is also known to be associated with a poor prognosis [1-4].

T. beigelii (T. cutaneum) was initially reported as the causative agent of this disease. However, it was reclassified into 20 species by the molecular evolution

Received 17 Oct. 2001; revised version accepted 20 Nov. 2001.

Corresponding author: Dr M. Nasu (e-mail: mnasu@oitamed.ac.jp). classification system, based on DNA-DNA homology, introduced by Guého et al. in 1992 [5]. According to the new classification, the species most often associated with deep-seated trichosporonosis are T. asahii and $T$. mucoides [6]; these are also the major causative agents of the summer-type of hypersensitivity pneumonitis. Thus, it is suggested that these fungi can cause hypersensitivity pneumonitis as allergens and deepseated trichosporonosis as pathogens, depending on the host's immunological status [7]. It is thought that these fungi enter the body via areas where indwelling vascular catheters and drainage tubes are inserted, via damaged skin areas in burn patients and by microbial translocation from the intestinal mucosa [8].

Several investigators have reported that clinical isolates of $T$. beigelii (the previous nomenclature included all 20 types of Trichosporon spp.) differ from environmental isolates in several phenotypes. Lee et al. [9] classified the morphological characteristics of $T$. beigelii and reported that morphologies of cells and 
colonies of isolates from deep-seated infection were different from those of environmental and superficial clinical isolates. Lyman et al. [10] also reported that clinical isolates of $T$. beigelii from deep-seated infection produced more glucuronoxylomannan (GXM) antigen than isolates from environmental sources or superficial infection, and they suggested that these differences might explain their pathogenicity.

In this regard, clinically important fungi such as Candida albicans and Cryptococcus neoformans are known to change their phenotype after repeated subcultures or in-vivo passages [11-16]. This process is thought to allow some fungi to escape eradication by the host immune system [11, 13-15]. However, to our knowledge, there are no studies that have previously examined phenotypic changes within the genus Trichosporon after passages in vivo.

This study compared the phenotypes of environmental isolates and clinical isolates (from deep-seated infections) of $T$. asahii with respect to morphological features and the release of GXM antigen and $(1 \rightarrow 3)-\beta$-D-glucan. Environmental isolates of $T$. asahii were also examined quantitatively for phenotypic changes after three passages in a murine host.

\section{Materials and methods}

\section{Organisms}

T. asahii isolates used in this study are listed in Table 1; there were 3 environmental isolates and 14 clinical isolates (which were stored in the Second Department of Internal Medicine at Oita Medical University). The clinical isolates were obtained from autopsy lungs, blood, urinary catheters, mediastinal drainage fluid, stool, venous catheters, urine and sputum samples. The environmental isolates, which were isolated from the floors of the houses of the patients with summer-type hypersensitivity pneumonitis, were kindly supplied by Teikyo University Research Center for Medical Mycol- ogy. All clinical isolates were identified as T. asahii var. asahii on the basis of DNA sequence homology analysis.

\section{Morphological examination}

T. asahii isolates, which were stored in skimmed milk suspension at $-80^{\circ} \mathrm{C}$, were cultured at $37^{\circ} \mathrm{C}$ for $48 \mathrm{~h}$ on Sabouraud Dextrose Agar (SDA; Eiken Chemical Co., Tokyo, Japan). All morphological examinations were performed on colonies grown from pinpoint inoculations on a new SDA plate at $37^{\circ} \mathrm{C}$ for 7 days. The growth of colonies was monitored macroscopically and classified by the method reported by Lee et al. [9]. T. asahii was inoculated with a platinum wire on to cornmeal medium (Nissui Pharmaceutical Co., Tokyo, Japan) and incubated at $37^{\circ} \mathrm{C}$ for $72 \mathrm{~h}$. The cell morphology was examined by light microscopy $(\times 400)$ and classified.

\section{Supernate preparation}

The method described by Lyman et al. [10] was used for supernate preparation. Briefly, T. asahii isolates that had been stored in skimmed milk suspension at $-80^{\circ} \mathrm{C}$ were cultured at $37^{\circ} \mathrm{C}$ for $48 \mathrm{~h}$ on SDA, subcultured at $37^{\circ} \mathrm{C}$ for $48 \mathrm{~h}$ on SDA, harvested with a platinum loop and suspended in and washed three times with endotoxin- and $(1 \rightarrow 3)-\beta$-D-glucan-free saline (Otsuka, Tokyo, Japan). In the next step, the T. asahii isolates $\left(1 \times 10^{6} \mathrm{cfu} / \mathrm{ml}\right)$ were incubated in RPMI 1640 containing $0.025 \mathrm{M}$ N-2-hydroxyethylpiperazine- $\mathrm{N}^{\prime}-2-$ ethane Sulphonic acid (HEPES) buffer and L-glutamine (Gibco BRL, Life Technologies, Tokyo, Japan) for $48 \mathrm{~h}$ at $37^{\circ} \mathrm{C}$ in a water bath with shaking. Immediately after this incubation, the cells were counted with a haemocytometer to determine the final density. The supernates were diluted with RPMI 1640 to prepare a fixed number of $1 \times 10^{6} \mathrm{cfu} / \mathrm{ml}$ so that the amount of antigen produced could be analysed on a per-cell basis. The cells were removed by centrifugation at $1500 \mathrm{~g}$ for $10 \mathrm{~min}$. To remove the cells completely, the supernates

Table 1. Morphology of the environmental isolates and clinical isolates

\begin{tabular}{llll}
\hline Isolate no. & Source & Colony & Cell \\
\hline TIMM1318 & Environment (floor) & Rugose & Hyphae \\
TIMM1574 & Environment (floor) & Rugose & Hyphae \\
TIMM1706 & Environment (floor) & Rugose & Hyphae \\
OU152 & Clinical (autopsy lung) & Powdery & Conidia \\
OU161 & Clinical (autopsy lung) & Powdery & Conidia \\
OU239 & Clinical (blood) & Powdery & Conidia \\
OU93001 & Clinical (urinary catheter) & Powdery & Conidia \\
NU93002 & Clinical (blood) & Powdery & Conidia \\
NU93003 & Clinical (mediastinal drained fluid) & Powdery & Mixed \\
OU94001 & Clinical (stool) & Powdery & Conidia \\
OU94002 & Clinical (venous catheter) & Powdery & Conidia \\
OU94003 & Clinical (urine) & Powdery & Conidia \\
OU94004 & Clinical (stool) & Powdery & Conidia \\
OU94005 & Clinical (urine) & Powdery & Conidia \\
OU94006 & Clinical (sputum) & Powdery & Conidia \\
OU94007 & Clinical (urinary catheter) & Powdery & Conidia \\
OU94008 & Clinical (stool) & Rugose & Conidia \\
\hline
\end{tabular}


were filtered with a Millex-GP sterilising filter (0.22$\mu \mathrm{m}$ pore size filter; Millipore, Bedford, MA, USA). The samples were stored at $-20^{\circ} \mathrm{C}$ until required for GXM antigen and $(1 \rightarrow 3)-\beta$-D-glucan assays.

\section{GXM antigen assay}

GXM antigen release in the supernates was determined semi-quantitatively with anticryptococcal cross-reactive antigen in a latex agglutination test. The assay kit used in this experiment was Serodirect 'Eiken' Cryptococcus $^{\circledR}$ (Eiken Chemical Co.). The assays were performed according to the manufacturer's instructions. Serial two-fold dilutions of each sample were prepared in RPMI 1640, and the titre was determined from the endpoint. Each assay was performed three times.

\section{$(1 \rightarrow 3)-\beta$-D-glucan assay}

Endotoxin- and $(1 \rightarrow 3)$ - $\beta$-D-glucan-free glassware and plasticware were used for the assay. Each sample was diluted to 1 in 10 and 1 in 100 with endotoxin- and $(1 \rightarrow 3)-\beta$-D-glucan-free distilled water (Otsuka). The assays were performed according to the instructions provided with the Fungitec $G^{\circledR}$ test kit (G test, Seikagaku Kogyo, Tokyo, Japan), but omitting the pre-treatment step for the removal of coagulase in the sample as the sample was not blood. Subsequently, $50 \mu 1$ of each diluted solution were mixed with $50 \mu 1$ of the main reagent of the $\mathrm{G}$ test kit in each well of a $(1 \rightarrow 3)$ - $\beta$-D-glucan-free 96 well plate (Toxipet Plate; Seikagaku). After incubation at $37^{\circ} \mathrm{C}$ for $30 \mathrm{~min}, 50 \mu \mathrm{l}$ each of sodium nitrite solution, ammonium sulphate solution and N-(1-naphthyl) ethylenediamine dihydrochloride were added to complete the diazo coupling reaction. Absorbance of each well was measured at a wavelength of $545 \mathrm{~nm}$ in a spectrophotometer (Multiscan Multisoft; Labsystems Japan, Tokyo, Japan). The $(1 \rightarrow 3)-\beta$-D-glucan value was obtained by comparison with the value for a standard solution. Each assay was performed three times.

\section{Preparation of passaged isolates}

Eight week-old male ICR mice (average weight, 28 SD $4 \mathrm{~g}$; Charles River Japan, Oita, Japan) were used in this study. Mice were fed dried food designed for experiments and, as prophylaxis against concurrent bacterial infections, they were provided with water containing vancomycin (VAN, Shionogi, Osaka, Japan) $50 \mu \mathrm{g} / \mathrm{ml}$ and gentamicin (GEN, Schering-Plough, Osaka, Japan) $10 \mu \mathrm{g} / \mathrm{ml}$. Each mouse was treated with an intraperitoneal injection of cyclophosphamide (CPM, Shionogi Co.) $200 \mathrm{mg} / \mathrm{kg} /$ day on days -3 and -2 and prednisolone (PSL, Shionogi) $30 \mathrm{mg} / \mathrm{kg} /$ day on day -1 to induce immunosuppression. Before inoculation, three environmental isolates of $T$. asahii were grown at $37^{\circ} \mathrm{C}$ for $48 \mathrm{~h}$ on SDA and then subcultured on to fresh SDA and incubated for a further $48 \mathrm{~h}$ to ensure purity and viability. Mature fungi were harvested and suspended in sterile distilled water and filtered through sterile gauze to remove the remaining agar and clumps of organisms. Serial 10-fold dilutions were made of each suspension in sterile distilled water and the organisms were counted with a haemocytometer. To confirm the haemocytometer count, diluted cell suspensions were cultured on SDA at $37^{\circ} \mathrm{C}$ for $48 \mathrm{~h}$. The fungal suspensions were diluted with distilled water and $0.3 \mathrm{ml}$ of the environmental isolate no. TIMM1318 $\left(7.5 \times 10^{5} \mathrm{cfu} /\right.$ mouse $), 0.3 \mathrm{ml}$ of isolate no. TIMM $1574\left(3.7 \times 10^{5} \mathrm{cfu} /\right.$ mouse $)$ and $0.3 \mathrm{ml}$ of isolate no. TIMM1706 $\left(3.0 \times 10^{6} \mathrm{cfu} /\right.$ mouse $)$ were individually injected into mice through the tail vein on day 0 . The inoculum size of each T. asahii isolate was selected so as to allow a survival rate of $100 \%$ in immunocompromised mice, as well as allow re-isolation of the fungi from the kidneys at 2 weeks. Two weeks later, the infected mice were killed by ether anaesthesia. Both kidneys were removed surgically and homogenised in $5 \mathrm{ml}$ of sterilised distilled water with a tissue homogeniser. The suspensions were filtered through sterile gauze and grown at $37^{\circ} \mathrm{C}$ for $48 \mathrm{~h}$ on SDA, followed by subculture at $37^{\circ} \mathrm{C}$ for $48 \mathrm{~h}$ on SDA. The fungi obtained were re-used for murine passage, samples were also stored in a skimmed milk suspension at $-80^{\circ} \mathrm{C}$ as the first passaged isolates. After three passages through mice, the second and third passaged isolates were prepared. The passaged isolates were examined morphologically and subjected to GXM antigen and $(1 \rightarrow 3)-\beta$-D-glucan assays. Each assay was performed three times. All animal experiments were performed according to the guidelines of the Ethical Committee for Animal Experiments at Oita Medical University.

\section{Statistical analysis}

Results of GXM antigen and $(1 \rightarrow 3)-\beta$-D-glucan assays are expressed as mean and SD. The unpaired Student's $t$ test and Welch's $t$ test were used for comparison between two groups. A p value of $<0.05$ was considered significant.

\section{Results}

\section{Morphological differences between environmental and clinical isolates}

Results of morphological analysis of colonies and cells of environmental and clinical isolates are summarised in Table 1. The colonial morphology was classified according to the method proposed by Lee et al. [9]. The 'rugose' type consisted of white, jagged, peaked colonies (Fig. 1a), whereas the 'powdery' type consisted of finely granulated colonies (Fig. 1b). There were clear differences between the colonial morphology and cell type of environmental and clinical isolates. Colonies of all environmental isolates were of the rugose type, whereas all clinical isolates, except for no. OU94008, were of the powdery type. Isolate OU94008 was of the rugose type. With regard to the 

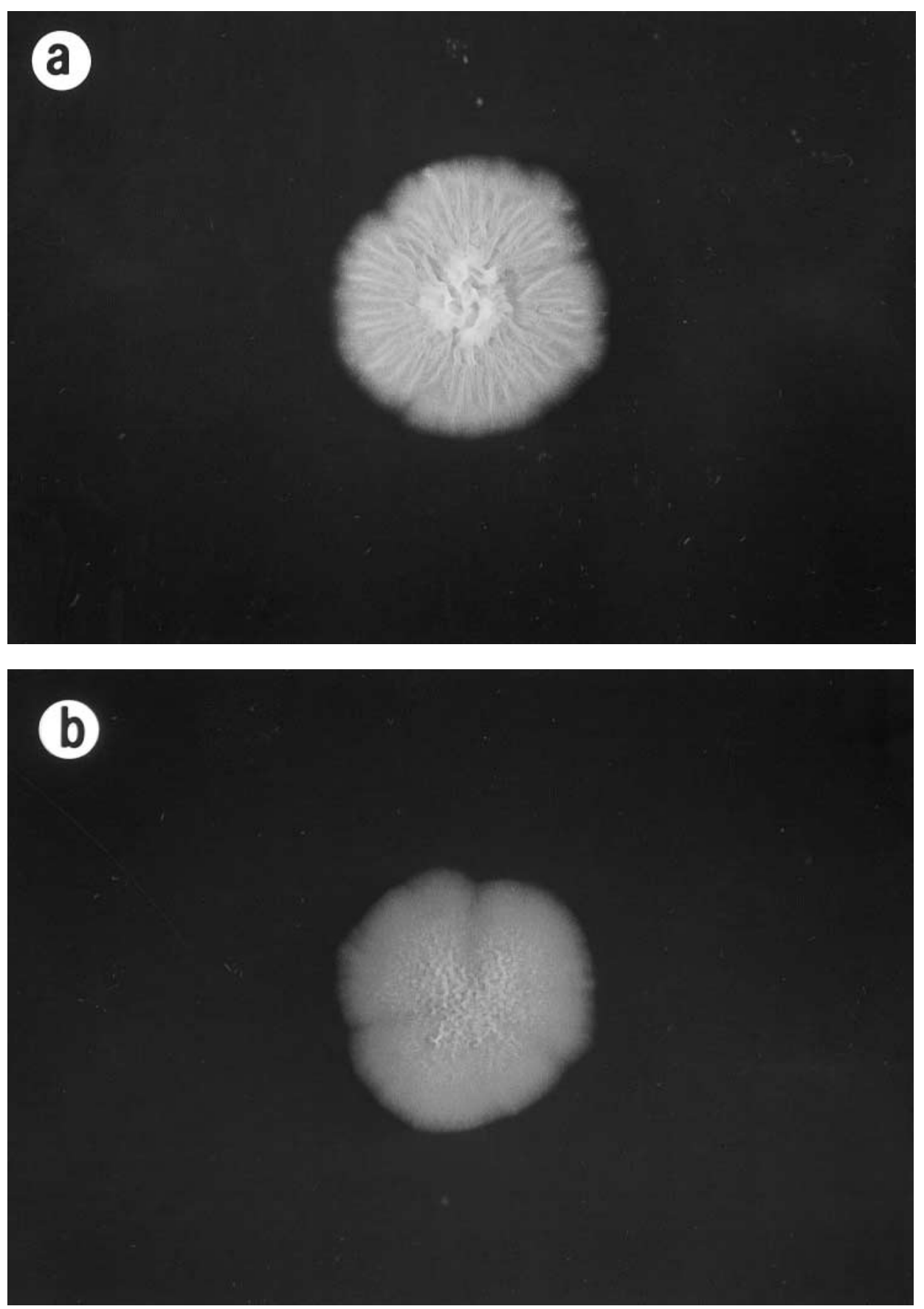

Fig. 1. Morphology of environmental and clinical isolates. For macroscopic examination, both isolates were cultured on SDA plates at $37^{\circ} \mathrm{C}$ for 7 days. (a) A representative environmental isolate (TIMM1706) showing a giant colony of the rugose type. (b) A representative clinical isolate (OMU239), showing a colony of the powdery type. For microscopic examination, both isolates were cultured by slide culture at $37^{\circ} \mathrm{C}$ for $72 \mathrm{~h}$. (c) A representative environmental isolate (TIMM1706) showing hyphae formation. (d) A representative clinical isolate $(\mathrm{OMU} 239)$ showing conidia formation (magnification $\times 400)$. Bars, $0.1 \mathrm{~mm}$.

cell type, environmental isolates consisted of $>99 \%$ hyphae (Fig. 1c), whereas all clinical isolates except for no. NU93003 consisted of $>90 \%$ blastoconidia and arthroconidia (Fig. 1d). Isolate NU93003 formed both conidia and hyphae in almost equal amounts and was consequently treated as a mixed pattern (Table 1).

GXM antigen and $(1 \rightarrow 3)-\beta$-D-glucan release by environmental and clinical isolates

Table 2 shows the results of GXM antigen and $(1 \rightarrow 3)$ - $\beta$-D-glucan assays in environmental and clin- ical isolates. The mean titre of GXM antigen in three environmental isolates was $\log _{2} 5.4$ SD 1.4 (range, $\log _{2} 3.7-\log _{2}$ 6.3) and the concentration of released $(1 \rightarrow 3)-\beta$-D-glucan was $374.3 \mathrm{SD} 411.0 \mathrm{pg} / \mathrm{ml}$ (range, $79.6-778.5 \mathrm{pg} / \mathrm{ml})$. The mean titre of GXM antigen in 14 strains of clinical isolates was $\log _{2} 9.4$ SD 0.7 (range, $\log _{2} 8.3-\log _{2} 10.3$ ) and the concentration of released $(1 \rightarrow 3)$ - $\beta$-D-glucan was $59.4 \mathrm{SD} 55.8 \mathrm{pg} / \mathrm{ml}$ (range, $23.3-153.8 \mathrm{pg} / \mathrm{ml}$ ). There were no significant differences in the values based on isolation sites among the clinical isolates. The mean titre of GXM antigen released by clinical isolates was significantly higher 

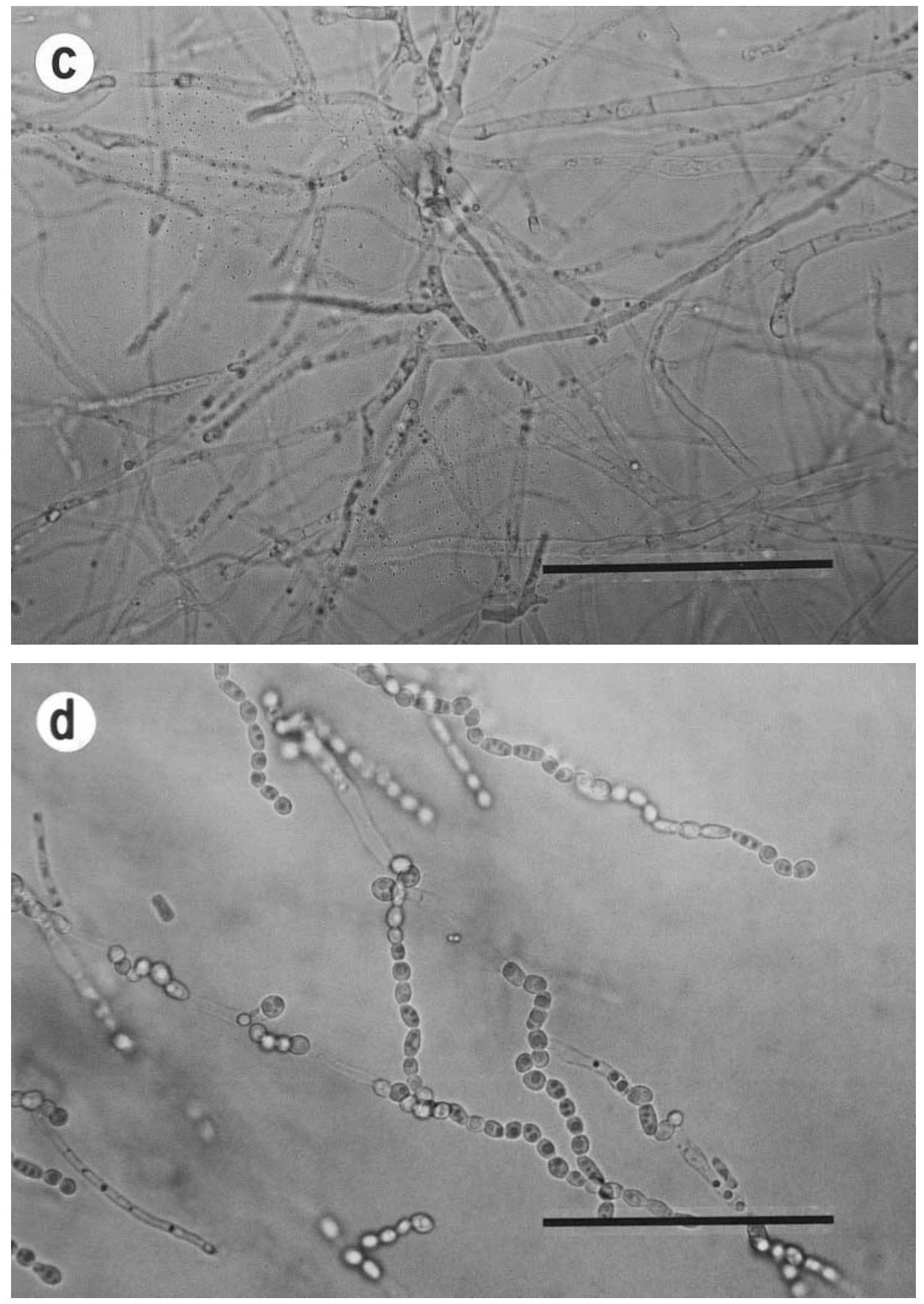

Fig. 1. (continued)

than that released by environmental isolates $(\mathrm{p}<0.01)$. In contrast, the mean concentration of $(1 \rightarrow 3)-\beta$-Dglucan released by environmental isolates was significantly higher than that released by clinical isolates $(\mathrm{p}<0.01)$.

\section{Comparison of morphological features between original and passaged environmental isolates}

Table 3 shows the results of analysis of morphological features of colonies and cells of the original environmental isolates and the same isolates after three passages through mice. With regard to the morphology of colonies, all original environmental isolates were of the rugose type as mentioned above (Fig. 2a), whereas all passaged isolates had changed to the powdery colony type (Fig. 2b). The cell morphology of all environmental isolates consisted of $>99 \%$ hyphae (Fig. $2 \mathrm{c})$, whereas all passaged environmental isolates except for TIMM1574 consisted of $>90 \%$ both blastoconidia and arthroconidia (Fig. 2d). Isolate TIMM1574 showed a mixed pattern.

GXM antigen and $(1 \rightarrow 3)-\beta$-D-glucan release by original and passaged environmental isolates

As shown in Table 3, the GXM antigen titre was significantly higher in all passaged isolates compared with the original environmental isolates. However, there was no significant difference in $(1 \rightarrow 3)-\beta$-D- 
Table 2. Comparison of phenotypes between environmental isolates and clinical isolates

\begin{tabular}{llcc}
\hline \multirow{2}{*}{ Source } & Isolate no. & $\begin{array}{c}\text { GXM antigen* } \\
\text { Mean }(\mathrm{SD}) \log _{2} \text { titre }\end{array}$ & $\begin{array}{c}(1 \rightarrow 3)-\beta \text {-D-glucan } \\
\text { Mean }(\mathrm{SD}) \mathrm{pg} / \mathrm{ml}\end{array}$ \\
\hline Environmental & TIMM1318 & $6.3(0.6)$ & $264.6(252.7)$ \\
& TIMM1574 & $3.7(0.6)$ & $79.6(24.1)$ \\
& TIMM1706 & $6.3(0.6)$ & $778.5(466.6)$ \\
Clinical & OU152 & $10.3(0.6)$ & $50.4(7.6)$ \\
& OU161 & $9.3(0.6)$ & $84.1(38.3)$ \\
& OU239 & $9.7(0.6)$ & $26.2(19.7)$ \\
& OU93001 & $9.3(0.6)$ & $34.9(2.5)$ \\
& NU93002 & $10.3(0.6)$ & $153.8(130.7)$ \\
& NU93003 & $8.3(0.6)$ & $23.3(4.1)$ \\
& OU94001 & $9.0(0.0)$ & $104.1(83.5)$ \\
& OU94002 & $9.0(0.0)$ & $37.9(31.2)$ \\
& OU94003 & $9.0(0.0)$ & $27.9(8.5)$ \\
& OU94004 & $10.3(0.6)$ & $73.8(79.5)$ \\
& OU94005 & $9.0(0.0)$ & $60.5(29.9)$ \\
& OU94006 & $9.3(0.6)$ & $63.8(16.9)$ \\
& OU94007 & $9.3(0.6)$ & $60.7(51.5)$ \\
\hline
\end{tabular}

${ }^{*}$ GXM antigen assay was performed three times for each isolate and expressed as mean (SD). $\dagger(1 \rightarrow 3)-\beta$-D-glucan assay was performed three times for each isolate and expressed as mean (SD).

Table 3. Comparison of phenotypes between original environmental isolates and passaged isolates

\begin{tabular}{lllcc}
\hline Isolate no. & Colony & Cell & $\begin{array}{c}\text { GXM antigen } \\
\text { Mean }(\mathrm{SD}) \log _{2} \text { titre }\end{array}$ & $\begin{array}{c}(1 \rightarrow 3)-\beta \text {-D-glucan } \\
\text { Mean }(\mathrm{SD}) \mathrm{pg} / \mathrm{ml}\end{array}$ \\
\hline $\begin{array}{l}\text { Original } \\
\text { TIMM1318 }\end{array}$ & Rugose & Hyphae & $6.3(0.6)$ & $264.6(252.7)$ \\
TIMM1574 & Rugose & Hyphae & $3.7(0.6)$ & $79.6(24.1)$ \\
TIMM1706 & Rugose & Hyphae & $6.3(0.6)$ & $778.5(466.6)$ \\
Passaged & & & & \\
TIMM1318 & Powdery & Conidia & $9.3(0.6)^{\ddagger}$ & $193.7(126.6)$ \\
TIMM1574 & Powdery & Mixed & $10.3(0.6)^{\ddagger}$ & $101.7(53.7)$ \\
TIMM1706 & Powdery & Conidia & $10.3(0.6)^{\ddagger}$ & $29.6(27.8)$ \\
\hline
\end{tabular}

${ }^{*}$ GXM antigen assay was performed three times for each isolate and expressed as mean (SD). $\dagger(1 \rightarrow 3)-\beta$-D-glucan assay was performed three times for each isolate and expressed as mean (SD).

${ }_{\mathrm{p}}<0.01$.

glucan release between each original and passaged isolate. The titre of released GXM antigen and concentration of $(1 \rightarrow 3)$ - $\beta$-D-glucan at each passage of the original environmental isolates are shown in Fig. 3. Passage through mice was clearly associated with a progressive increase in GXM antigen release, but there were no clear changes in $(1 \rightarrow 3)-\beta$-D-glucan release. The mean titre of GXM antigen in three passaged environmental isolates was significantly higher than that of the original environmental isolates $\left(\log _{2} 10.0\right.$ $\mathrm{SD} 0.7$ versus $\left.\log _{2} 5.4 \mathrm{SD} 1.4, \mathrm{p}<0.01\right)$. However, there was no clear difference in $(1 \rightarrow 3)$ - $\beta$-D-glucan value between the two groups (108.3 SD 99.9 versus 374.3 SD 411.0, NS).

\section{Discussion}

It has been reported that clinical isolates of $T$. beigelii differ from environmental isolates in several phenotypes $[9,10]$. Based on these early studies, the present study compared the phenotypes of environmental isolates and clinical isolates of $T$. asahii. The concentration of $(1 \rightarrow 3)-\beta$-D-glucan released by environmental isolates was higher than that by clinical isolates. We propose the following explanation for the finding that the environmental isolates released more $(1 \rightarrow 3)-\beta$-D-glucan than the clinical isolates. As $(1 \rightarrow 3)-\beta$-D-glucan is a polysaccharide forming the major structural component of the fungal cell wall $[17,18]$, the amount of $(1 \rightarrow 3)-\beta$-D-glucan released must depend on the surface area of a cell. The surface area of cells differs depending on whether they are in the form of hyphae or conidia (the surface area of a hypha should be larger than that of a conidium). The environmental isolates of $T$. asahii grow as hyphae whereas the clinical isolates grow as conidia. Therefore, when equal numbers of the environmental isolates and clinical isolates are compared according to the methods of Lyman et al. [10], the environmental isolates released more $(1 \rightarrow 3)$ - $\beta$-D-glucan into the supernates than clinical isolates. 

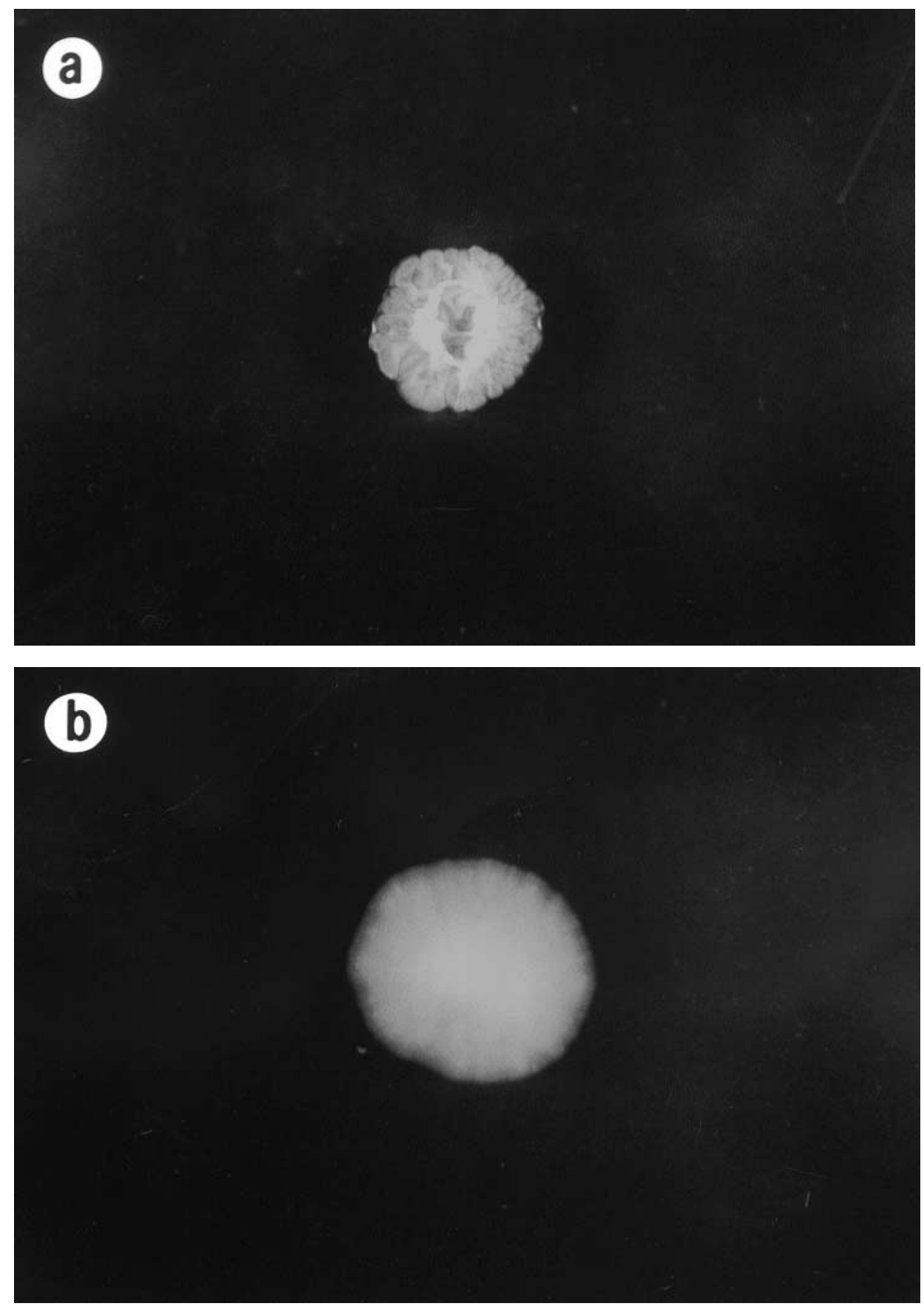

Fig. 2. Morphology of a representative environmental isolate (TIMM1318) before and after three passages in mice. Note the change from a giant rugose colony in the original isolate (a) to a powdery pattern in the passaged isolate (b). Note also formation of hyphae in the original isolate (c) and formation of conidia in the passaged isolate (d) (magnification $\times 400)$. Bars, $0.1 \mathrm{~mm}$.

On the other hand, the level of GXM antigen released in the supernates of clinical isolates was higher than in environmental isolates. GXM antigen of T. beigelii is an extractable, heat-stable antigen that shares antigenic determinants with glucuronoxylomannan of the capsular polysaccharide of Crypt. neoformans [19]. GXM antigen is localised to the cell wall and to fibrillar extracellular matrix projecting from the cell wall of $T$. beigelii $[20,21]$. The significantly higher GXM antigen titre in clinical isolates relative to that in environmental isolates is likely to be due to a higher release of GXM antigen from the organisms, as it cannot simply be explained by differences in the cell surface area.
Previous studies have shown that $C$. albicans and Crypt. neoformans change their phenotypes when they are subcultured repeatedly or passaged in vivo [11-16]. C. albicans spontaneously switches the morphology of its colonies into at least seven general phenotypes [16]. Crypt. neoformans also changes its phenotype including colony type, capsule size, melanin production, GXM structure, virulence for mice, sterol composition and antifungal susceptibility after passages in vitro and in vivo $[11,12,14,15]$. Furthermore, serial Crypt. neoformans isolates from the same patients were shown to differ with respect to their ability to survive in vivo, virulence in a murine model of cryptococcosis, in-vitro 

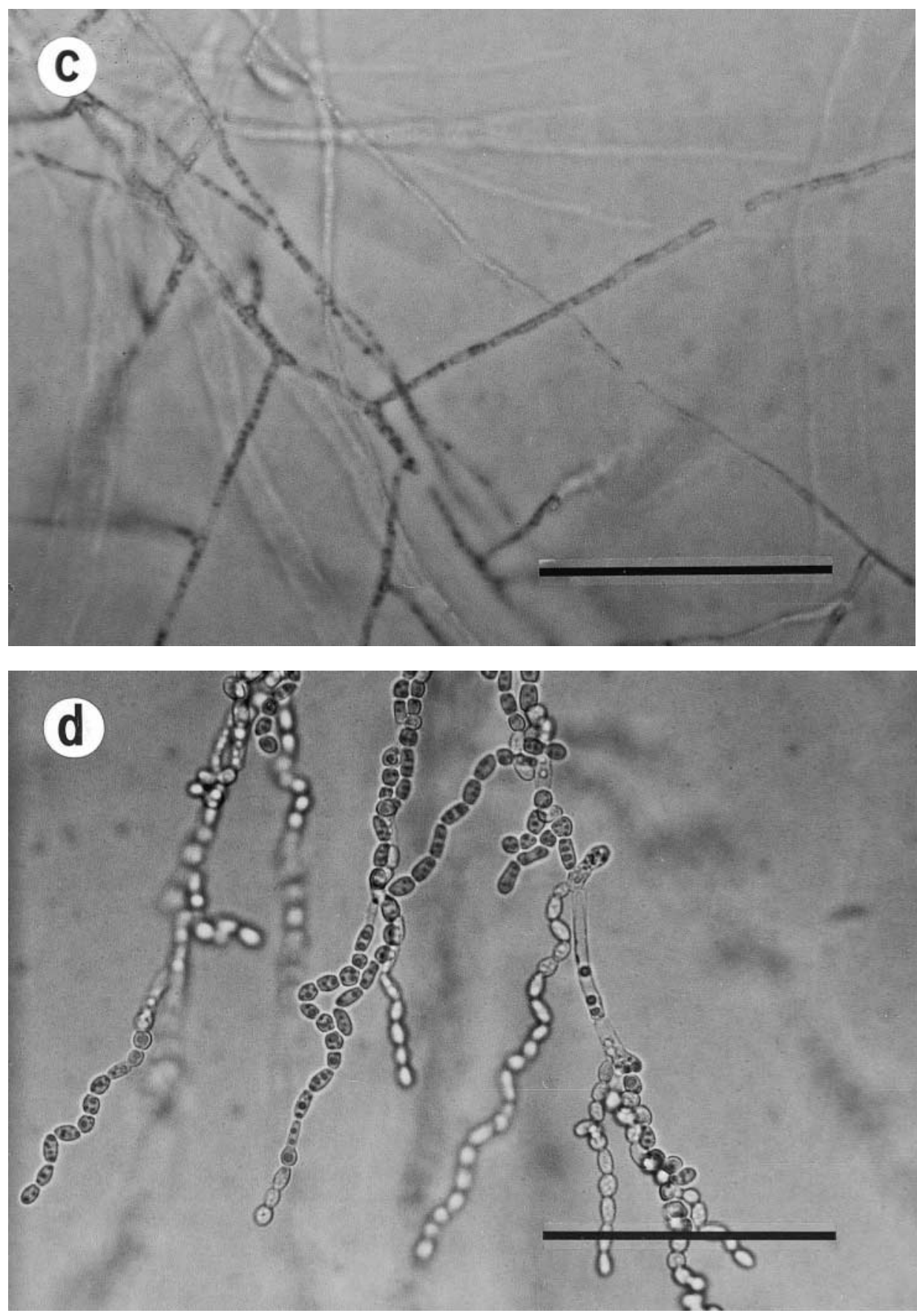

Fig. 2. (continued)

growth rates at $37^{\circ} \mathrm{C}$ and capsule size [13]. It is thought that environmental adaptation brings about phenotypic variations of the fungus after passages in vitro or in vivo, especially after passages in vivo. Therefore, phenotypic changes may play an important role in the ability of the fungus to escape host defences and establish persistent infection.

To our knowledge, there has been no previous report concerning the phenotypic changes of Trichosporon species after passages in vivo. This study investigated the phenotypic changes of $T$. asahii due to passages in vivo. The results of morphological study suggest that passages in vivo in mice change the morphology of environmental isolates to that of clinical isolates.
All isolates showed an increased GXM titre after each passage through the mouse. The capsular GXM polysaccharide from Crypt. neoformans is thought to be antiphagocytic to polymorphonuclear leucocytes and, thus, is an important virulence factor for this organism [22-24]. Like Crypt. neoformans, T. beigelii is also quite resistant to phagocytosis by polymorphonuclear leucocytes and monocytes, and highly resistant compared with $C$. albicans $[25,26]$. Although $T$. beigelii is not a capsulate organism, its phylogenetic relationship to Crypt. neoformans has been established [27, 28]. The restricted phagocytosis of T. beigelii is thought to be related to its surface component, GXM antigen, and a correlation has been reported between GXM antigen production and resistance to killing by polymorpho- 

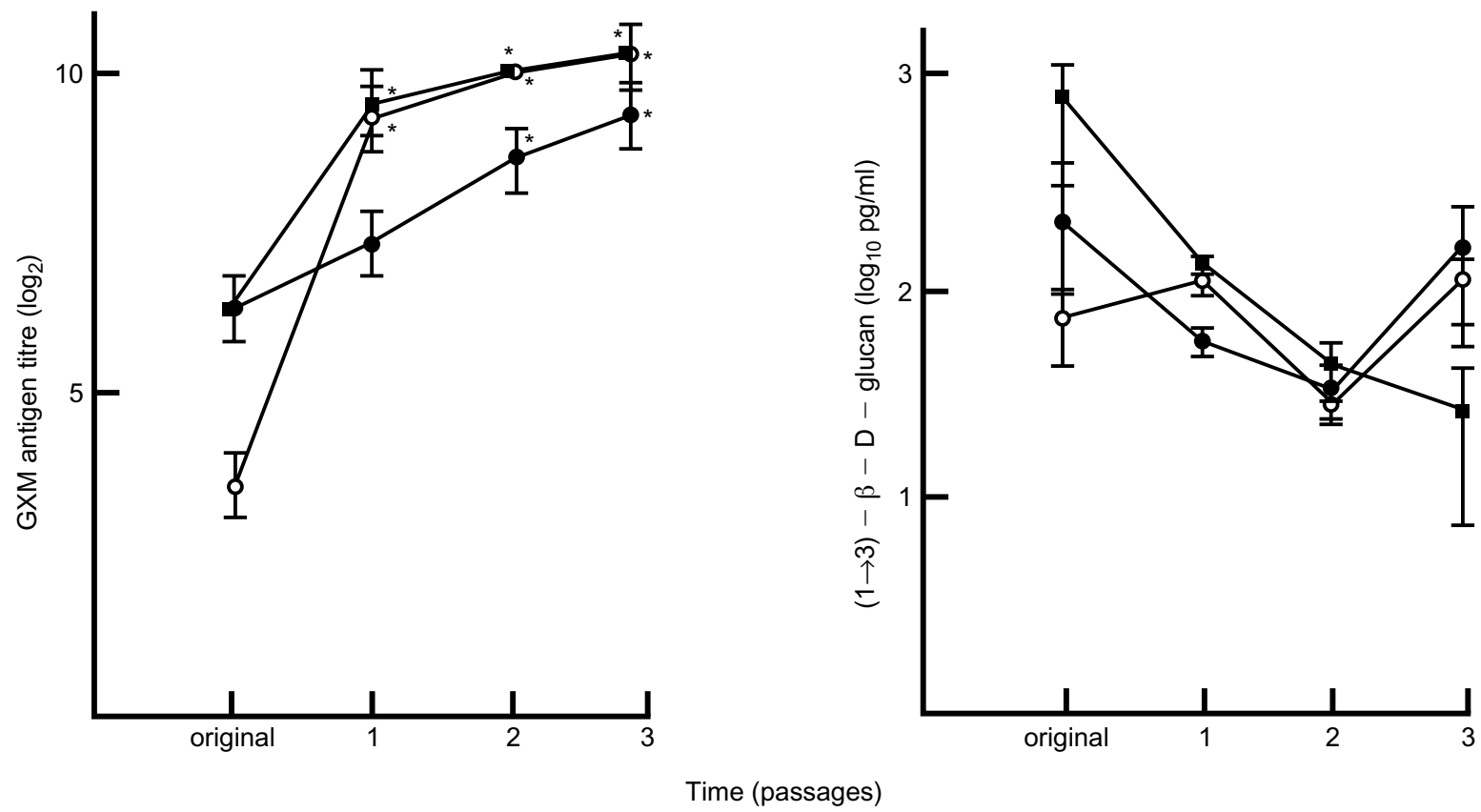

Fig. 3. Serial changes in GXM antigen titre and $(1 \rightarrow 3)-\beta$-D-glucan concentration in supernates of environmental isolates at passages 1,2 and 3 in mice. (a) Note the gradual and progressive increase in antigen titre after each passage. (b) (1 $\rightarrow 3)-\beta$-Dglucan concentrations showed no significant changes after passages. ${ }^{*} \mathrm{p}<0.01$ versus original. $\bullet$, TIMM 1318; $\bigcirc$, TIMM 1574; 口, TIMM 1706.

nuclear leucocytes and monocytes $[25,26]$. Previous studies have shown that GXM antigen is involved in the pathogenicity of $T$. beigelii and that differences in the production of this antigen between environmental and clinical isolates result in the characteristic differences between them [10]. However, in the present study, passages in vivo were associated with increased release of GXM antigen. The results of the present study suggest that the increased release of GXM antigen is not a result of differences in fungal characteristics, but stems from fungus-host interactions, and is a means of enabling the fungus to escape phagocytosis by polymorphonuclear leucocytes and monocytes in vivo. This process may allow a proportion of the fungal population to escape eradication by the host immune system and establish persistent infection. Thus, brain abscess due to persistent $T$. beigelii infection has been reported [29]. Clinically, phenotypic changes in Trichosporon as well as in $C$. albicans and Crypt. neoformans may play an important role in the persistence of infection.

Previous reports suggest that phenotypic variations of C. albicans and Crypt. neoformans are associated with karyotypic changes resulting from micro-evolution $[13,14,30]$. As karyotype analyses were not performed in the present study, it is not possible to say whether the phenotypic changes in T. asahii are a result of micro-evolution or phenotypic adaptation. However, clinical isolates and environmental isolates passaged in mice did not demonstrate any morphological conversions after repeated subcultures over a 3-month period at room temperature (data not shown). This is indicative of in-vivo selection of the new phenotypically stable variations.

These results are particularly useful for the identification of T. asahii in clinical microbiology laboratories, because they indicate that the marked morphological variations occurring both macroscopically and microscopically appear to follow certain patterns in clinical isolates and that systemic pathogens differ from environmental isolates in morphological features and release of GXM antigen.

Further studies are necessary to determine whether this process results from karyotypic changes and alters the pathogenicity of the organism. Studies specifically designed to examine the survival rate and persistence of environmental $T$. asahii isolates in various murine body organs are currently being conducted in this department.

We thank Takako Shinoda, Meiji College of Pharmacy, for performing tests for the identification of $T$. asahii by DNA-DNA homology. We also thank Atsuro Hashimoto, Perparim Kamberi and Hiroyuki Nagai for their technical support, and J.P. Maskell (Department of Medical Microbiology, St Bartholomew's and the Royal London School of Medicine and Dentistry, UK) for careful reading and editing of the manuscript.

\section{References}

1. Hoy J, Hsu K-C, Rolston K, Hopfer RL, Luna M, Bodey GP. Trichosporon beigelii infection: a review. Rev Infect Dis 1986; 8: $959-967$.

2. Itoh $\mathrm{T}$, Hosokawa $\mathrm{H}$, Kohdera $\mathrm{U}$, Toyazaki N, Asada $\mathrm{Y}$. Disseminated infection with Trichosporon asahii. Mycosis 
1996; 39: 195-199.

3. Kataoka-Nishimura S, Akiyama $\mathrm{H}$, Saku $\mathrm{K}$ et al. Invasive infection due to Trichosporon cutaneum in patients with hematologic malignancies. Cancer 1998; 82: 484-487.

4. Walling DM, McGraw DJ, Merz WG, Karp JE, Hutchins GM. Disseminated infection with Trichosporon beigelii. Rev Infect Dis 1987; 9: 1013-1019.

5. Guého E, Smith MT, de Hoog GS, Billion-Grand G, Christen $\mathrm{R}$, Batenburg-van der Vegte WH. Contributions to a revision of the genus Trichosporon. Antonie Van Leeuwenhoek 1992; 61: 289-316.

6. Guého E, Improvisi L, de Hoog GS, Dupont B. Trichosporon on humans: a practical account. Mycosis 1994; 37: 3-10.

7. Nishiura Y, Nakagawa-Yoshida K, Suga M, Shinoda T, Guého E, Ando M. Assignment and serotyping of Trichosporon species: the causative agents of summer-type hypersensitivity pneumonitis. J Med Vet Mycol 1997; 35: 45-52.

8. Tashiro T, Nagai H, Nagaoka H, Goto Y, Kamberi P, Nasu M. Trichosporon beigelii pneumonia in patients with hematologic malignancies. Chest 1995; 108: 190-195.

9. Lee JW, Melcher GA, Rinaldi MG, Pizzo PA, Walsh TJ. Patterns of morphologic variation among isolates of Trichosporon beigelii. J Clin Microbiol 1990; 28: 2823-2827.

10. Lyman CA, Devi SJN, Nathanson J, Frasch CE, Pizzo PA, Walsh TJ. Detection and quantitation of the glucuronoxylomannan-like polysaccharide antigen from clinical and nonclinical isolates of Trichosporon beigelii and implications for pathogenicity. J Clin Microbiol 1995; 33: 126-130.

11. Currie B, Sanati H, Ibrahim AS, Edwards JE, Casadevall A, Ghannoum MA. Sterol compositions and susceptibilities to amphotericin B of environmental Cryptococcus neoformans isolates are changed by murine passage. Antimicrob Agents Chemother 1995; 39: 1934-1937.

12. Franzot SP, Mukherjee J, Cherniak R, Chen L-C, Hamdan JS, Casadevall A. Microevolution of a standard strain of Cryptococcus neoformans resulting in differences in virulence and other phenotypes. Infect Immun 1998; 66: 89-97.

13. Fries BC, Casadevall A. Serial isolates of Cryptococcus neoformans from patients with AIDS differ in virulence for mice. J Infect Dis 1998; 178: 1761-1766.

14. Fries BC, Goldman DL, Cherniak R, Ju R, Casadevall A. Phenotypic switching in Cryptococcus neoformans results in changes in cellular morphology and glucuronoxylomannan structure. Infect Immun 1999; 67: 6076-6083.

15. Goldman DL, Fries BC, Franzot SP, Montella L, Casadevall A. Phenotypic switching in the human pathogenic fungus Cryptococcus neoformans is associated with changes in virulence and pulmonary inflammatory response in rodents. Proc Natl Acad Sci USA 1998; 95: 14967-14972.

16. Slutsky B, Buffo J, Soll DR. High-frequency switching of colony morphology in Candida albicans. Science 1985; 230: 666-669.

17. Miyazaki T, Kohno S, Mitsutake K, Maesaki S, Tanaka K,
Hara K. ( $1 \rightarrow 3$ )- $\beta$-D-glucan in culture fluid of fungi activates factor G, a limulus coagulation factor. J Clin Lab Anal 1995; 9: 334-339.

18. Obayashi T, Yoshida M, Mori $\mathrm{T}$ et al. Plasma $(1 \rightarrow 3)-\beta$-Dglucan measurement in diagnosis of invasive deep mycosis and fungal febrile episodes. Lancet 1995; 345: 17-20.

19. McManus EJ, Jones JM. Detection of a Trichosporon beigelii antigen cross-reactive with Cryptococcus neoformans capsular polysaccharide in serum from a patient with disseminated Trichosporon infection. J Clin Microbiol 1985; 21: 681-685.

20. Melcher GP, Reed KD, Rinaldi MG, Lee JW, Pizzo PA, Walsh TJ. Demonstration of a cell wall antigen cross-reacting with cryptococcal polysaccharide in experimental disseminated trichosporonosis. J Clin Microbiol 1991; 29: 192-196.

21. Walsh TJ, Lee JW, Melcher GP et al. Experimental Trichosporon infection in persistently granulocytopenic rabbits: implications for pathogenesis, diagnosis, and treatment of an emerging opportunistic mycosis. J Infect Dis 1992; 166: $121-133$.

22. Diamond RD, Root RK, Bennett JE. Factors influencing killing of Cryptococcus neoformans by human leukocytes in vitro. J Infect Dis 1972; 125: 367-376.

23. Kozel TR, Pfrommer GST, Guerlain AS, Highison BA, Highison GJ. Role of the capsule in phagocytosis of Cryptococcus neoformans. Rev Infect Dis 1988; 10(Supp1): S436-S439.

24. Kozel TR, Mastroianni RP. Inhibition of phagocytosis by Cryptococcal polysaccharide: dissociation of the attachment and ingestion phases of phagocytosis. Infect Immun 1976; 14 62-67.

25. Lyman CA, Garrett KF, Pizzo PA, Walsh TJ. Response of human polymorphonuclear leukocytes and monocytes to Trichosporon beigelii; host defense against an emerging opportunistic pathogen. J Infect Dis 1994; 170: 1557-1565.

26. Lyman CA, Walsh TJ. Phagocytosis of medically important yeasts by polymorphonuclear leukocytes. Infect Immun 1994; 62: $1489-1493$.

27. Guého E, Improvisi L, Christen R, de Hoog GS. Phylogenic relationships of Cryptococcus neoformans and some related basidiomycetous yeasts determined from partial large subunit rRNA sequences. Antonie Van Leeuwenhoek 1993; 63: $175-189$.

28. Fan M, Currie BP, Gutell RR, Ragen MA, Casadevall A. The 16S-like, 5.8S and 23S-like rRNAs of the two varieties of Cryptococcus neoformans: sequence, secondary structure, phylogenetic analysis and restriction fragment polymorphisms. J Med Vet Mycol 1994; 32: 163-180.

29. Watson KC, Kallichurum S. Brain abscess due to Trichosporon cutaneum. J Med Microbiol 1970; 3: 191-193.

30. Fries BC, Chen F, Currie BP, Casadevall A. Karyotype instability in Cryptococcus neoformans infection. $J$ Clin Microbiol 1996; 34: 1531-1534. 